\title{
FAKTOR YANG MEMPENGARUHI NIAT IBU MEMBERIKAN ASI EKSKLUSIF DI KELURAHAN MAGERSARI, SIDOARJO
}

\author{
INFLUENCING FACTORS OF THE INTENTIONS MOTHERS BREASTFEEDING \\ EXCLUSIVELY IN KELURAHAN MAGERSARI, SIDOARJO
}

\author{
Arifa Yusrina, Shrimarti Rukmini Devy \\ Departemen Promosi Kesehatan dan Ilmu Perilaku \\ Fakultas Kesehatan Masyarakat, Universitas Airlannga Surabaya \\ Email : yusrinaarifa05@yahoo.com
}

\begin{abstract}
Breastmilk is a the milk produced by the breast of mother which created specially by God. It was produced according to the needs of infants who were born by a mother. Exclusive breastfeeding is the process of feeding a baby only from breastmilk without other supplementary food until baby is 6 month. One of the factors that affect the behavior of breastfeeding is the intention of a mother to breastfeed. The objective of this study is to analyze the factors which affect the mother's intention to exclusively breastfeed in Kelurahan Magersari, Sidoarjo. This study is an observational analytic study with a quantitative approach. This study used cross-sectional study design. The sample of this study were 60 pregnant women who were society's member of Kelurahan Magersari, Sidoarjo. Independent variables of this study are attitude (behavioral beliefs and evaluation of behavioral outcomes) and subjective norm (normative beliefs and motivation to comply). Study results were obtained from questionnaire. Analysis technique applied is logistic regression test in order to know which factors affect the mother's intention. The dependent variable of this study is the mother's intention to exclusively breastfeed. The research result are from questionnaire. The results obtained that the factors that influence on intention to provide breastmilk exclusively are behavioral beliefs $(\operatorname{sig}=0.008$, with the $\operatorname{Exp}(B)=173,443)$ and motivation to comply (sig $=0.006$, with the Exp $(B)=32,114)$, owned by the mother associated with exclusive breast. The conclusions there are two factors that affect the mother's intention to provide breastmilk exclusively in Kelurahan Magersari, Sidoarjo there are behavioral beliefs and motivation to comply.
\end{abstract}

Keywords: affect, intention, exclusively breastfeeding

\begin{abstract}
Abstrak: Air Susu Ibu (ASI) adalah cairan yang diciptakan khusus oleh Tuhan yang keluar langsung dari payudara seorang ibu untuk bayinya. ASI diciptakan sesuai dengan kebutuhan bayi yang dilahirkan oleh seorang ibu. Pemberian ASI Eksklusif merupakan proses pemberian makan pada bayi yang berupa ASI saja tanpa makanan tambahan lain hingga bayi berumur 6 bulan. Salah satu faktor yang mempengaruhi perilaku menyusui yaitu niat seorang ibu untuk menyusui. Tujuan dari penelitian ini adalah untuk menganalisis faktor yang mempengaruhi niat ibu untuk memberikan ASI Eksklusif di Kelurahan Magersari Sidoarjo. Penelitian menggunakan pendekatan kuantitatif dengan jenis penelitian observasional dan tergolong cross sectional. Sampel dalam penelitian ini yaitu ibu hamil yang merupakan warga tetap di wilayah penelitian sebanyak 60 responden. Variabel independen penelitian yaitu karakteristik ibu yang terdiri dari umur, pendidikan, pendapatan, pengetahuan, pekerjaan, sikap yang terdiri dari keyakinan berperilaku dan evaluasi hasil, dan norma subyektif yang terdiri dari keyakinan terhadap norma dan keinginan untuk meniru. Variabel dependen penelitian yaitu niat ibu untuk memberikan ASI Eksklusif. Hasil penelitian didapat melalui kuesioner. Penelitian menggunakan uji regresi logistik yang bertujuan untuk melihat faktor yang berpengaruh antara variabel independen terhadap variabel dependen. Hasil didapatkan bahwa faktor yang berpengaruh terhadap niat untuk memberikan ASI Eksklusif yaitu keyakinan berperilaku ( $\operatorname{sig}=0,008$, dengan $\operatorname{Exp}(B)=173,443)$ dan keinginan meniru $(\operatorname{sig}=0.006$, with the $\operatorname{Exp}(\mathrm{B})=32,114$ ) yang dimiliki oleh ibu terkait dengan pemberian ASI Eksklusif . Kesimpulan didapat bahwa terdapat dua faktor yang berpengaruh terhadap niat ibu untuk memberikan ASI Eksklusif di Kelurahan Magersari, Sidoarjo yaitu keyakinan berperilaku dan keinginan meniru yang dimiliki oleh ibu.
\end{abstract}

Kata kunci : pengaruh, niat, ASI eksklusif 


\section{PENDAHULUAN}

Air Susu Ibu (ASI) adalah cairan yang diciptakan khusus yang keluar langsung dari payudara seorang ibu untuk bayi. ASI merupakan makanan bayi yang paling sempurna, praktis, murah dan bersih karena langsung diminum dari payudara ibu. ASI mengandung semua zat gizi dan cairan yang dibutuhkan bayi untuk memenuhi kebutuhan gizi di 6 bulan pertamanya. Jenis ASI terbagi menjadi 3 yaitu kolostrum, ASI masa peralihan dan ASI mature. Kolostrum adalah susu yang keluar pertama, kental, berwarna kuning dengan mengandung protein tinggi dan sedikit lemak (Walyani, 2015).

Kandungan ASI antara lain yaitu sel darah putih, zat kekebalan, enzim pencernaan, hormon dan protein yang sangat cocok untuk memenuhi kebutuhan hingga bayi berumur 6 bulan. ASI mengandung karbohidrat, protein, lemak, multivitamin, air, kartinin dan mineral secara lengkap yang sangat cocok dan mudah diserap secara sempurna dan sama sekali tidak mengganggu fungsi ginjal bayi yang sedang dalam tahap pertumbuhan. Komposisi ASI dipengaruhi oleh stadium laktasi, ras, keadaan nutrisi, dan diit ibu (Soetjiningsih, 2012).

ASI dihasilkan oleh kelenjar payudara melalui proses laktasi. Pemberian ASI perlu karena memberikan beberapa manfaat bagi bayi antara lain, dapat memberikan kehidupan yang baik dalam pertumbuhan maupun perkembangan bayi, mengandung antibodi yang melindungi bayi dari penyakit infeksi bakteri, virus, jamur, dan parasit, mengandung komposisi yang tepat karena kandungan ASI diciptakan sesuai dengan kebutuhan bayi, meningkatkan kecerdasan bayi, terhindar dari alergi yang biasanya timbul karena konsumsi susu formula, bayi merasakan kasih sayang ibu secara langsung saat proses menyusui, dan ketika beranjak dewasa akan mengurangi risiko untuk terkena hipertensi, kolesterol, overweight, obesitas dan diabetes tipe 2. Bayi yang tidak diberikan ASI eksklusif akan lebih rentan untuk terkena penyakit kronis, seperti jantung, hipertensi, dan diabetes setelah ia dewasa serta dapat menderita kekurangan gizi dan mengalami obesitas.

Pemberian ASI eksklusif selain bermanfaat bagi bayi juga bermanfaat bagi ibu diantaranya sebagai kontrasepsi alami saat ibu menyusui dan sebelum menstruasi, menjaga kesehatan ibu dengan mengurangi risiko terkena kanker payudara dan membantu ibu untuk menjalin ikatan batin kepada anak. Pemberian ASI dapat membantu mengurangi pengeluaran keluarga karena tidak membeli susu formula yang harganya mahal (Walyani, 2015).

Proses pemberian ASI tanpa makanan tambahan lain pada bayi berumur 0-6 bulan disebut ASI eksklusif. ASI eksklusif yang dimaksud yaitu bayi tidak diberikan apapun, kecuali makanan yang langsung diproduksi oleh ibu yaitu ASI (Yuliarti, 2010). World Health Organization (WHO) dan United Nation Childrens Fund (UNICEF) merekomendasikan sebaiknya anak hanya diberi air susu ibu (ASI) selama paling sedikit enam bulan pertama dalam kehidupan seorang bayi dan dilanjutkan dengan makanan pendamping yang tepat sampai usia 2 tahun dalam rangka menurunkan angka kesakitan dan kematian anak.

Kadangkala ibu mendapatkan informasi yang salah tentang manfaat ASI eksklusif, mengenai cara menyusui yang benar, dan apa yang harus dilakukan bila timbul kesukaran dalam menyusui. Proses pemberian ASI bisa saja mengalami hambatan dikarenakan produksi ASI berhenti (Febriyanti, Rosalina dan Dwi Ernawati, 2015). Hambatan dalam pemberian ASI Eksklusif antara lain ASI keluar sedikit, ibu takut payudara turun, dan ibu bekerja. Beberapa faktor yang mempengaruhi penggunaan ASI eksklusif antara lain faktor pengetahuan, faktor meniru teman, faktor sosial budaya, faktor psikologis, faktor fisik ibu, faktor perilaku, faktor tenaga kesehatan (Soetjiningsih, 2012).

Faktor pengetahuan dan informasi yang didapat akan mempengaruhi niat seorang ibu untuk memberikan ASI Eksklusif. Faktor yang berpengaruh terhadap niat ibu hamil dalam memberikan ASI Eksklusif yaitu usia kehamilan, norma sosial, pekerjaan ibu, dan pengalaman menyusui ibu (Jatmika, 2015). Niat adalah kehendak atau keinginan dalam hati seseorang ingin melakukan sesuatu perilaku. Niat erat kaitannya dengan motivasi, yaitu dorongan yang timbul dalam 
diri seseorang secara sadar untuk melakukan suatu tindakan dengan tujuan tertentu. Niat untuk melakukan atau tidak melakukan suatu perilaku dipengaruhi oleh dua penentu dasar yaitu sikap dan norma subyektif.

Seseorang akan memiliki niat yang kuat jika informasi yang dimilikinya cukup kuat untuk meyakinkannya bahwa perilaku tersebut layak untuk dilakukan. Niat yang sudah dimiliki seseorang, hendaknya diperkuat dengan menambah pengetahuan mengenai ASI baik keunggulan, komposisi, manfaat, dan keutamaannya. Pengetahuan diperlukan untuk memantapkan niat ibu untuk memberikan ASI (Nurani, 2013).

Theory of resoned action menyebutkan bahwa perilaku merupakan suatu tindakan yang timbul akibat adanya niat yang dimiliki seseorang. Niat (intention to perform behavior) merupakan transisi dari kepercayaan atau keyakinan yang dimiliki seseorang menuju suatu tindakan yang diinginkan. Niat akan muncul setelah adanya sikap positif dan dukungan normatif dari lingkungan sekitar untuk melakukan suatu perilaku. Niat seseorang dalam theory of reasoned action dipengaruhi oleh sikap dan norma subyektif yang dimiliki dan dipercayainya. Sikap (attitude toward behavior) dipengaruhi oleh behavioral beliefs dan evaluation of behavioral outcomes. Norma subyektif (subjective norms) dipengaruhi oleh normative beliefs dan motivation to comply (Glanz, 2008). Tinggi rendahnya niat ibu hamil untuk memberikan ASI Eksklusif akan berdampak pada tinggi rendahnya cakupan pemberian ASI Eksklusif.

Berdasarkan data Profil Provinsi Jawa Timur, menyebutkan bahwa cakupan ASI eksklusif pada bayi $0-6$ bulan pada Tahun 2012 sebesar 58,20\%. Persentase cakupan mengalami peningkatan pada Tahun 2013 yaitu sebesar 70,8\%. Pada Tahun 2014 persentase cakupan ASI sebesar $74 \%$. Cakupan ASI eksklusif di Kabupaten Sidoarjo pada tahun 2010 sebesar 26,29\%. Tahun 2011 bayi yang mendapatkan ASI eksklusif sebesar 44,6\%. Tahun 2012, persentase cakupan ASI Eksklusif sebesar 51,16\% (Kementrian Kesehatan RI, 2014).

Berdasarkan data awal yang diperoleh dari pihak Puskesmas Sidoarjo, bagian Poli
Gizi diketahui bahwa semua kelurahan yang berada di wilayah kerja Puskesmas Sidoarjo memiliki persentase cakupan ASI Eksklusif di bawah target nasional. Wilayah kerja Puskesmas Kabupaten Sidoarjo antara lain kelurahan Magersari, Pucang, Kemiri, Bluru kidul, Sidokumpul, Sidoklumpuk, Sidokare, Lemah Putro dan Pekauman. Cakupan ASI eksklusif di wilayah Puskesmas Sidoarjo pada Tahun 2012 sebesar 59,36\%. Tahun 2013 sebesar 29,4\%. Tahun 2014, sebesar 46,4\% (Laporan Puskesmas Sidoarjo, 2015).

Wilayah Kelurahan Magersari yang dipilih menjadi lokasi penelitian memiliki cakupan ASI eksklusif pada Tahun 2013 sebesar 62,50\%. Tahun 2015 sebesar 52,9\% (Laporan Puskesmas Sidoarjo, 2015). Berdasarkan data cakupan yang ada terlihat bahwa cakupan ASI eksklusif sudah mulai mengalami peningkatan, namun masih berada jauh dari target nasional yaitu sebesar $80 \%$.

Berdasarkan latar belakang tersebut, maka perlu dilakukan penelitian tentang analisis faktor yang mempengaruhi niat ibu untuk memberikan ASI eksklusif dengan theory of reasoned action di Kelurahan Magersari, Sidoarjo. Batasan masalah dalam penelitian ini yaitu penelitian hanya dilakukan pada ibu hamil yang merupakan penduduk yang tinggal di Kelurahan Magersari wilayah kerja Puskesmas Sidoarjo. Tujuan penelitian yaitu untuk menganalisis faktor yang mempengaruhi niat ibu untuk memberikan ASI Eksklusif dengan menggunakan theory of reasoned action di Kelurahan Magersari Sidoarjo.

\section{METODE}

Penelitian menggunakan pendekatan kuantitatif dengan jenis observasional analitik, karena peneliti tidak memberikan perlakuan apapun terhadap responden (Notoatmodjo, 2012). Rancang bangun penelitian tergolong cross sectional.

Populasi dalam penelitian ini yaitu seluruh ibu hamil yang merupakan penduduk tetap yang tinggal di wilayah Kelurahan Magersari, Sidoarjo dengan jumlah 66 orang. Pengambilan sampel dilakukan secara simple random sampling. Besar sampel 
dalam penelitian berdasarkan perhitungan dengan rumus Slovin didapatkan sejumlah 57 responden dan dibulatkan menjadi 60 responden.

Lokasi penelitian yaitu di wilayah Kelurahan Magersari, Kecamatan Sidoarjo. Pemilihan lokasi berdasarkan cakupan dan rekomendasi dari pihak Puskesmas Sidoarjo. Waktu penelitian berlangsung pada bulan Desember 2015 hingga Mei 2016.

Variabel independen penelitian yaitu sikap (attitude toward behavior) dipengaruhi oleh behavioral beliefs dan evaluation of behavioral outcomes dan norma subyektif (subjective norms) dipengaruhi oleh normative beliefs dan motivation to comply (Glanz, 2008). Variabel dependen penelitian yaitu niat ibu untuk memberikan ASI Eksklusif.

Jenis data dalam penelitian menggunakan data primer. Data primer didapat melalui kuesioner. Kuesioner telah diuji validitas dan reliabilitas. Pengumpulan data dilakukan dengan mengunjungi rumah responden, membacakan PSP, mengisi inform consent dan responden menjawab pertanyaan dalam kuesioner. Jumlah pertanyaan dalam kuesioner sejumlah 20 butir soal.

Skala pengukuran untuk melihat pengetahuan menggunakan skala Guttman yaitu dengan pilihan benar dan salah. Kategori skor untuk pengetahuan dibagi menjadi 3 yaitu baik (76-100\%), cukup $(56-75 \%)$, dan kurang $(<55 \%)$. Pengukuran sikap dan norma subyektif yaitu dengan skala Likert. Skor dikelompokkan Kategori keyakinan berperilaku yaitu sangat tidak mendukung skor 4-8, tidak mendukung skor 9-13, mendukung skor 14-18 dan sangat mendukung skor 19-23. Kategori evaluasi hasil, yaitu sangat tidak mendukung skor 4 7, tidak mendukung skor 8-11, mendukung skor $12-15$, dan sangat mendukung skor 16-20. Kategori keyakinan normatif, yaitu sangat tidak mendukung skor 4-7, tidak mendukung skor 8-11, mendukung skor $12-15$, dan sangat mendukung skor $16-$ 20. Kategori keinginan untuk meniru, yaitu sangat tidak mendukung skor 4-6, tidak mendukung skor 7-9, mendukung skor 10 12 , dan sangat mendukung skor 13-16.
Teknik pengolahan data melalui proses editing, coding, entry,dan analysis. Penelitian dianalisis menggunakan software SPSS 21, dengan menggunakan metode uji regresi logistik multivariat yang digunakan untuk melihat pengaruh dari varibel independen yaitu oleh behavioral beliefs, evaluation of behavioral outcomes, normative beliefs dan motivation to comply terhadap variabel dependen yaitu niat ibu untuk memberikan ASI Eksklusif. Variabel dikatakan berpengaruh apabila nilai signifikansi $<0,050$.

\section{HASIL PENELITIAN}

Hasil penelitian meliputi karakteristik responden, sikap (attitude toward behavior) dipengaruhi oleh behavioral beliefs dan evaluation of behavioral outcomes dan norma subyektif (subjective norms) dipengaruhi oleh normative beliefs dan motivation to comply. Karakteristik responden dalam penelitian meliputi umur, pendidikan, pekerjaan, pendapatan dan pengetahuan yang dimiliki oleh ibu hamil di Kelurahan Magersari, Sidoarjo. Berikut merupakan distribusi karakteristik responden penelitian. Tabel 1 menunjukkan distribusi karakteristik responden penelitian

Tabel 1. Karakteristik Responden di Kelurahan Magersari, Sidoarjo

\begin{tabular}{lcc}
\hline \multicolumn{1}{c}{$\begin{array}{c}\text { Karakteristik } \\
\text { Responden }\end{array}$} & $\mathbf{N}$ & $\mathbf{\%}$ \\
\hline Umur & 17 & 28,3 \\
12-25 tahun & 43 & 71,7 \\
26-45 tahun & 3 & 5 \\
\hline Pendidikan & 4 & 6,7 \\
$\quad$ SD/sederajat & 29 & 48,3 \\
SMP/sederajat & 24 & 40 \\
SMA/sederajat & & \\
PT/sederajat & 30 & 50 \\
Pekerjaan & 6 & 10 \\
Ibu Rumah Tangga & 24 & 40 \\
PNS & & \\
Swasta & 43 & 71,7 \\
\hline Pendapatan & 17 & 28,3 \\
$\quad$ Tinggi & & \\
Rendah & 58 & 96,7 \\
\hline Pengetahuan & 1 & 1,7 \\
Baik & 1 & 1,7 \\
Cukup & & \\
Kurang &
\end{tabular}


dan diperoleh hasil bahwa mayoritas responden yang menjadi sampel penelitian yaitu ibu yang berusia 26-45 tahun sejumlah 43 responden (71,7\%). Rentang usia 26-45 tahun termasuk dalam masa dewasa. Mayoritas responden berpendidikan tinggi dengan pendidikan terakhir yang ditempuh responden adalah tamat SMA/ sederajat sejumlah 29 responden $(48,3 \%)$. Mayoritas responden berstatus sebagai ibu rumah tangga sejumlah 30 responden (50\%). Pendapatan responden mayoritas rendah yaitu di bawah UMK Kabupaten Sidoarjo sebesar Rp. 3.040.000 sejumlah 43 responden $(71,7 \%)$. Mayoritas responden memiliki pengetahuan baik terhadap pemberian ASI Eksklusif sejumlah 58 responden $(96,7 \%)$.

Sikap (attitude) dalam theory of reasoned action terdiri dari behavioral beliefs dan evaluation of behavioral outcomes. Sikap ibu dalam penelitian ini dilihat melalui kedua variabel tersebut. Behavioral beliefs dalam penelitian ini diartikan sebagai keyakinan berperilaku. Evaluation of behavioral outcomes dalam penelitian ini diartikan sebagai evaluasi hasil perilaku. Berikut merupakan distribusi responden terhadap variabel yang terdapat dalam sikap:

Tabel 2 menunjukkan bahwa sejumlah $51 \mathrm{ibu}$ sangat mendukung pemberian ASI Eksklusif yang berasal dari pertimbangan keuntungan maupun kerugian atas keyakinan berperilaku yaitu pemberian ASI Eksklusif untuk bayinya. Ibu yang termasuk dalam kategori mendukung terhadap keyakinan berperilaku sejumlah 9 responden.

Keyakinan berperilaku ibu digambarkan melalui pernyataan yang meliputi anjuran pemberian ASI Eksklusif, kecukupan

Tabel 2. Distribusi Sikap Ibu di Kelurahan Magersari Kabupaten Sidoarjo Tahun 2016.

\begin{tabular}{lcc}
\hline Sikap & N & \% \\
\hline Keyakinan berperilaku & & \\
Sangat mendukung & 51 & 85 \\
Mendukung & 9 & 15 \\
\hline Evaluasi hasil & & \\
Sangat mendukung & 55 & 91,7 \\
Mendukung & 5 & 8,3 \\
\hline
\end{tabular}

pemberian ASI untuk bayi, manfaat ASI yang dapat membuat bayi sehat, pemberian ASI Eksklusif dapat memperkuat ikatan batin antara ibu dan anak, pemberian ASI itu praktis, higienis, tanpa menggunakan botol, dan keuntungan pemberian ASI karena tidak mengeluarkan biaya. Mayoritas responden sangat setuju pada poin pernyataan yang menjelaskan tentang pemberian ASI Eksklusif mendekatkan ikatan kasih antara ibu dan anak.

Berdasarkan tabel 2 didapatkan bahwa mayoritas ibu sangat mendukung terkait evaluasi hasil pemberian ASI Eksklusif yang berasal dari pertimbangan atas konsekuensi yang didapat baik positif maupun negatif dalam pemberian ASI Eksklusif untuk bayinya sejumlah $55 \mathrm{ibu}$. Ibu yang termasuk dalam kategori mendukung terhadap evaluasi hasil untuk memberikan ASI Eksklusif sejumlah 5 responden.

Evaluasi hasil ibu dilihat melalui pernyataan yang meliputi ASI membuat bayi sehat, ASI dapat menghindarkan bayi dari penyakit infeksi, pemberian ASI dapat menghemat pengeluaran, pemberian ASI mendekatkan ikatan batin antara ibu dan anak, dan pemberian ASI eksklusif dapat membuat ibu sehat. Pernyataan mayoritas yang dipilih ibu yaitu pernyataan pemberian ASI mendekatkan ikatan kasih antara ibu dan anak. Pernyataan mayoritas yang dipilih responden dengan pilihan sangat setuju yaitu tentang ASI dapat memperkuat ikatan batin antara ibu dan anak.

Norma subyektif berasal dari faktor sosial yang menghasilkan tekanan sosial yang dirasakan ibu untuk melakukan atau tidak melakukan suatu perilaku. Sumber norma subyektif berasal dari lingkungan terdekat, dan lingkungan sosial. Orang yang berada di dalam lingkungan sosial yang dapat mempengaruhi keyakinan seseorang antara lain orang tua, teman dekat, dan seseorang yang mampu mendorong seseorang untuk melakukan atau tidak melakukan suatu perilaku. Norma subyektif (subjectif norm) dalam theory of reasoned action terdiri dari normative beliefs dan motivation to comply. Normative beliefs dalam penelitian diartikan sebagai keyakinan normatif. Motivation to comply dalam penelitian diartikan sebagai keinginan meniru. 
Tabel 3. Distribusi Norma Subyektif Ibu di Kelurahan Magersari Kabupaten Sidoarjo Tahun 2016.

\begin{tabular}{lcc}
\hline Norma Subyektif & N & \% \\
\hline Keyakinan normatif & & \\
Sangat mendukung & 49 & 81,7 \\
Mendukung & 8 & 13,3 \\
Tidak mendukung & 3 & 5 \\
\hline Keinginan meniru & & \\
Sangat mendukung & 37 & 61,7 \\
Mendukung & 19 & 31,7 \\
Tidak mendukung & 4 & 6,7 \\
\hline
\end{tabular}

Berdasarkan data tabel 3 dapat dilihat bahwa mayoritas keyakinan normatif responden sangat mendukung untuk memberikan ASI Eksklusif sejumlah 49 responden. Keyakinan normatif yaitu kepercayaan yang menghasilkan suatu keyakinan dari lingkungan terdekat seorang ibu. Responden yang mendukung terhadap keyakinan normatif untuk memberikan ASI Eksklusif sejumlah 8 responden. Responden yang tidak mendukung terhadap keyakinan normatif untuk memberikan ASI Eksklusif sejumlah 3 responden.

Keyakinan normatif dilihat melalui pernyataan tentang suami yang harus mendukung untuk memberikan ASI Eksklusif, pemberian ASI Eksklusif sudah dilakukan secara turun-temurun, orang tua mendukung untuk memberikan ASI Eksklusif, petugas kesehatan harus mengarahkan untuk memberikan ASI Eksklusif selama periksa kehamilan dan banyak ibu di lingkungan sekitar yang berhasil memberikan ASI Eksklusif. Pernyataan mayoritas yang dipilih responden dengan pilihan sangat setuju yaitu tentang suami harus mendukung untuk memberikan ASI Eksklusif.

Berdasarkan tabel 3, didapatkan bahwa mayoritas keinginan meniru responden sangat mendukung untuk melakukan pemberian ASI Eksklusif sejumlah 37 responden. Responden yang mendukung terhadap keinginan meniru sejumlah 19 responden. Reponden yang tidak mendukung terhadap keinginan untuk meniru sejumlah 4 responden.

Keinginan meniru meliputi keberhasilan teman dalam memberikan ASI Eksklusif, keberhasilan yang dialami oleh orang tua (ibu) yang memotivasi untuk meniru, keberhasilan tetangga yang memberikan ASI Eksklusif pada anaknya, dan melihat anak teman yang sehat karena pemberian ASI Eksklusif. Pernyataan yang mayoritas dipilih responden dengan pilihan sangat setuju yaitu tentang keberhasilan yang dialami orang tua khususnya ibu dapat memotivasi untuk memberikan ASI Eksklusif.

Niat (intention) dalam theory of reasoned action dipengaruhi oleh sikap dan norma subyektif seseorang. Niat adalah keinginan seseorang untuk bertindak sehubungan dengan stimulus yang didapatnya (Notoatmodjo, 2012). Cara terbaik untuk mengetahui suatu kehendak seseorang dalam melakukan suatu perilaku yaitu dengan mengetahui niatnya (Jatmika, 2015). Niat dalam penelitian dibagi menjadi dua kategori yaitu berniat dan tidak berniat untuk memberikan ASI Eksklusif.

Tabel 4. menunjukkan bahwa mayoritas responden berniat untuk memberikan ASI eksklusif sejumlah 53 ibu. Ibu yang berniat untuk memberikan ASI eksklusif dikarenakan manfaat ASI yang baik kepada ibu maupun anak, menghemat pengeluaran, praktis langsung diberikan kepada bayi, dan membuat bayi sehat menguatkan antibodi bayi. Sedangkan, responden yang tidak berniat untuk memberikan ASI Eksklusif sejumlah $7 \mathrm{ibu}$. Ibu yang tidak berniat memberikan ASI Eksklusif dikarenakan pengalaman sebelumnya tidak menyusui, ibu bekerja dan ibu memiliki pendapat bahwa ASI yang dimilikinya belum mampu membuat bayi kenyang sehingga perlu susu formula sebagai tambahan.

Faktor yang mempengaruhi niat ibu untuk memberikan ASI Eksklusif di Kelurahan Magersari, Sidoarjo berdasarkan hasil uji regresi logistik yaitu:

Tabel 4. Distribusi Niat Responden Untuk Memberikan ASI Eksklusif di Kelurahan Magersari, Sidoarjo Tahun 2016

\begin{tabular}{lcc}
\hline \multicolumn{1}{c}{ Niat } & n & \% \\
\hline Berniat & 53 & 88,3 \\
Tidak berniat & 7 & 11,7 \\
\hline
\end{tabular}


Tabel 5. Hasil Uji Regresi Multivariat

\begin{tabular}{|c|c|c|}
\hline Variabel & Sig & Keterangan \\
\hline $\begin{array}{l}\text { Keyakinan } \\
\text { berperilaku }\end{array}$ & 0,008 & Berpengaruh \\
\hline Evaluasi hasil & 0,051 & $\begin{array}{c}\text { Tidak } \\
\text { berpengaruh }\end{array}$ \\
\hline $\begin{array}{l}\text { Keyakinan } \\
\text { Normatif }\end{array}$ & 0,764 & $\begin{array}{c}\text { Tidak } \\
\text { berpengaruh }\end{array}$ \\
\hline $\begin{array}{l}\text { Keinginan } \\
\text { meniru }\end{array}$ & 0,006 & Berpengaruh \\
\hline
\end{tabular}

Tabel 5 menunjukkan bahwa terdapat dua faktor yang mempengaruhi niat ibu untuk memberikan ASI Eksklusif di Kelurahan Magersari, Sidoarjo yaitu keyakinan berperilaku dan keinginan meniru. Hasil penelitian sesuai dengan teori yang menyatakan bahwa niat seseorang dapat dipengaruhi oleh keyakinan berperilaku dan keinginan meniru agar terjadinya suatu perilaku yang diinginkan seseorang.

\section{PEMBAHASAN}

Karakteristik individu dalam theory of reasoned action termasuk dalam variabel demografi. Variabel demografi merupakan variabel yang dapat mempengaruhi sikap dan norma subyektif seseorang untuk melakukan suatu perilaku. Karakteristik individu dalam penelitian meliputi umur, pendidikan terakhir, status pekerjaan, pendapatan dan tingkat pengetahuan ibu tentang ASI Eksklusif.

Mayoritas ibu hamil termasuk dalam usia dewasa dengan rentang usia 26-45 tahun. Dewasa merupakan suatu periode dimana seseorang sudah mulai menyesuaikan diri terhadap pola kehidupan sosial yang ada, karena pada masa ini seseorang sudah mulai memainkan suatu peranan dalam berkehidupan. Usia dapat melatarbelakangi seseorang untuk melakukan suatu perilaku, karena setiap kelompok umur memiliki pandangan yang berbeda. Ibu yang berada pada masa dewasa akan lebih mengerti dan paham terhadap suatu hal dibandingkan dengan ibu yang belum memasuki usia dewasa (Kurniawati, 2014).

Mayoritas ibu memiliki tingkat pendidikan yang tinggi. Pendidikan terakhir yang ditempuh ibu hamil merupakan lulusan SMA/sederajat. Menurut Undang-
Undang No. 20 Tahun 2003 tentang Sistem Pendidikan Nasional, pendidikan merupakan usaha sadar dan terencana untuk mewujudkan suasana belajar dan proses pembelajaran agar peserta didik secara aktif dapat mengembangkan potensi dirinya, kepribadian, kecerdasan, akhlak mulia, serta keterampilan yang diperlukan dirinya (Undang-undang Republik Indonesia No. 20 Tahun 2003). Semakin tinggi tingkat pendidikan seseorang, maka semakin mudah pula seseorang untuk menerima informasi. Informasi yang didapat seseorang nantinya akan mempengaruhi pengetahuan (Kurniawati, 2014).

Mayoritas pekerjaan ibu hamil dalam penelitian berstatus sebagai ibu rumah tangga. Ibu rumah tangga adalah wanita yang mengatur berbagai macam pekerjaan rumah tangga. Ibu rumah tangga atau ibu yang tidak bekerja diluar rumah akan mempunyai banyak waktu untuk mengurus keluarga dibandingkan dengan ibu bekerja diluar rumah (Roesli, 2008).

Mayoritas responden memiliki pendapatan rendah. Pendapatan akan mempengaruhi pemberian ASI Eksklusif, karena semakin tinggi pendapatan, maka semakin kecil kemungkinan terjadinya perilaku pemberian ASI Eksklusif (Sulistyowati, 2014).

Mayoritas ibu hamil memiliki pengetahuan yang baik terhadap ASI Eksklusif. Pengetahuan adalah hasil penginderaan seseorang, atau hasil tahu seseorang terhadap suatu obyek melalui indera yang dimilikinya (Notoatmodjo, 2012). Penelitian Kurniawati (2014) menyimpulkan bahwa baik atau tidaknya pengetahuan seseorang tidak berdampak terhadap pemberian ASI Eksklusif untuk bayinya.

Karakteristik atau latar belakang seseorang di dalam Theory of Reasoned Action secara langsung dapat mempengaruhi sikap dan norma subyektif terhadap niat dan perilaku yang akan dipilihnya. Menurut Jatmika (2015), karakteristik responden bukan faktor yang berhubungan erat dengan niat secara langsung untuk memberikan ASI Eksklusif. Melainkan dalam TRA, menyebutkan bahwa karakteristik responden merupakan faktor eksternal dan efeknya 
tidak langsung kepada niat melainkan secara langsung mempengaruhi sikap dan norma subyektif.

Sikap merupakan respon tertutup yang dihasilkan seseorang terhadap stimulus yang diterimanya, dengan melibatkan faktor pendapat dan emosi yang bersangkutan untuk setuju atau tidak setuju terhadap suatu perilaku (Notoatmodjo, 2005). Theory of reasoned action menyatakan bahwa ada 2 varibel yang mempengaruhi sikap (attitude) yaitu behavioral beliefs dan evaluation of behavioral outcomes.

Keyakinan berperilaku merupakan kepercayaan yang dimiliki ibu dalam mempertimbangkan keuntungan dan kerugian yang dirasakan ibu untuk memiliki niat memberikan ASI Eksklusif. Mayoritas responden memiliki pandangan sangat mendukung terhadap keyakinan berperilaku. Terlihat bahwa ibu dalam berperilaku sangat memerhatikan keuntungan dan kerugian yang dirasakan ibu dalam penerapan perilaku pemberian ASI Eksklusif. Mayoritas ibu memilih pernyataan tentang pemberian ASI dapat menumbuhkan ikatan batin antara ibu dan anak. Pemberian ASI akan menghasilkan hubungan ikatan batin yang kuat antara ibu dan anak. Bayi yang sering berada dalam dekapan ibunya saat menyusui akan merasakan kasih sayang, rasa aman, tenteram dan terlindung. Nantinya perasaan terlindung dan sayang inilah yang akan menjadi dasar perkembangan emosi anak. Perkembangan emosi akan berhubungan dengan kepribadian anak (Danuatmaja, Bonny dan Mila Meiliasari, 2013).

Evaluasi hasil adalah hasil yang didapat dari konsekuensi positif maupun negatif yang dirasakan ibu yang mempengaruhi niat untuk memberikan ASI Eksklusif. Berdasarkan hasil penelitian, mayoritas responden sangat mendukung terhadap evaluasi hasil pemberian ASI Eksklusif. Pernyataan evaluasi hasil untuk memberikan ASI Eksklusif, mayoritas ibu hamil memiliki pandangan bahwa pemberian ASI dapat menumbuhkan hubungan ikatan batin antara ibu dan anak. Kegiatan menyusui atau pemberian ASI Eksklusif dapat membantu ibu dan bayi dalam membentuk tali kasih. Timbulnya rasa kasih terjadi saat proses menyusui yang nantinya akan menumbuhkan ikatan psikologis antara ibu dan anak (Yuliarti, 2010). Menurut Nisa (2009), menyatakan bahwa tidak ada pengaruh sikap terhadap pemberian ASI non eksklusif dikarenakan responden yang memiliki sikap sedang dapat memberikan dapat memiliki perilaku memberikan ASI Ekslusif.

Norma subyektif ibu dalam penelitian ini diartikan sebagai pandangan ibu terhadap kepercayaan yang dimiliki orang lain atau keluarga yang sering berada di sekitar ibu untuk mempengaruhi dirinya dalam menentukan suatu niat terhadap perilaku pemberian ASI Eksklusif. Norma subyektif didapat ibu dari keadaan lingkungan sosial ibu tinggal atau bersosialisasi. Lingkungan sosial memiliki pengaruh yang cukup besar terhadap terjadinya suatu perilaku, karena kebiasaan yang menghasilkan norma sosial dan telah dijalani secara turun temurun atau kebiasaan (Kurniawati, 2014). Pembahasan norma subyektif dalam penelitian terdiri dari normative beliefs dan motivation to comply.

Keyakinan normatif adalah keyakinan ibu yang diperoleh dari keluarga maupun lingkungan sekitar yang mempengaruhi niat untuk melakukan suatu perilaku. Mayoritas responden pandangan sangat mendukung terhadap keyakinan normatif. Terlihat dari jumlah responden terhadap pernyataan dapat diketahui bahwa ibu hamil akan memperhatikan pandangan orang sekitar dalam melakukan suatu perilaku. Mayoritas responden memilih pernyataan yang menyatakan bahwa suami harus mendukung untuk melakukan pemberian ASI Eksklusif. Hal ini sesuai dengan penelitian Kurniawati (2014) yang menyatakan bahwa dukungan ayah/suami sangat penting dalam keberhasilan perilaku menyusui terutama untuk ASI Eksklusif.

Dukungan emosinal suami sangat berarti bagi ibu, karena ayah/suami menjadi benteng pertama bagi ibu untuk menentukan keputusan. Menurut Ida (2012), menyatakan bahwa ibu yang didukung baik oleh suami berpeluang lebih besar berperilaku memberikan ASI Eksklusif 6 bulan dibandingkan dengan ibu yang memperoleh dukungan yang kurang dari suami. 
Pada dasarnya, ayah juga memiliki peran penting dalam proses menyusui karena bagi istri seorang suami adalah orang terdekat yang diharapkan selalu ada disisinya dan selalu siap untuk memberikan bantuan. Motivasi ibu akan bertambah jika mendapat dukungan dari suami untuk menambah kepercayaan dirinya untuk dapat melakukan pemberian ASI Eksklusif. Menurut Jatmika (2015), menyatakan bahwa tidak ada hubungan antara dukungan suami dengan niat ibu hamil dalam memberikan ASI Eksklusif di Wilayah Kerja Puskesmas Gondokusuman, Kota Yogyakarta.

Keinginan meniru adalah keinginan ibu untuk memberikan ASI Eksklusif yang didapat dari dukungan lingkungan sekitar yang dapat mempengaruhi niatnya. Teman atau orang terdekat merupakan sumber dorongan terkuat ibu dalam melakukan pemberian ASI Eksklusif (Kurniawati, 2014). Berdasarkan hasil penelitian, mayoritas responden mendukung terhadap keinginan meniru. Mayoritas responden dalam penelitian memilih pernyataan bahwa keberhasilan ibu, membuat ibu berkeinginan untuk memberikan ASI Eksklusif. Keinginan meniru ibu hamil di Kelurahan Magersari didapatkan dari hasil kebiasaan yang terjadi dalam keluarga, terutama ibu yang menurunkan perilaku kepada anaknya untuk menyusui dengan memberikan ASI Eksklusif. Kebiasaan yang dilakukan secara turun-temurun akan sangat mempengaruhi suatu perilaku.

Penelitian Kurniawati (2014) yang menyatakan bahwa faktor norma sosial budaya memiliki pengaruh yang besar terhadap pemberian ASI Eksklusif. Faktor norma sosial budaya yang dapat mempengaruhi terjadinya suatu perilaku yang diperoleh dari teman, tetangga atau personal reference.

Norma sosial yang terdapat dalam masyarakat membawa dampak terhadap pemberian ASI Eksklusif. Peran keluarga sangat penting terhadap praktik pemberian ASI Eksklusif. Penelitian milik Jatmika (2015) juga menyatakan bahwa terdapat hubungan antara norma subyektif terhadap niat ibu hamil untuk memberikan ASI Eksklusif di wilayah Kerja Puskesmas Gondokusuman, Yogyakarta.
Niat adalah keinginan seseorang untuk bertindak sehubungan dengan stimulus yang didapatnya (Notoatmodjo, 2012). Niat ibu dalam penelitian diartikan sebagai suatu kehendak atau keinginan yang dimiliki ibu untuk memberikan ASI eksklusif. Niat ibu untuk memberikan ASI Eksklusif merupakan langkah sebelum terjadinya perilaku pemberian ASI Eksklusif. Dalam theory of reasoned action menyatakan bahwa niat dipengaruhi oleh sikap dan norma subyektif seseorang.

Berdasarkan hasil penelitian, mayoritas ibu memiliki niat untuk memberikan ASI Eksklusif. Alasan ibu untuk memberikan ASI Eksklusif diantaranya ibu menginginkan bayinya sehat, kandungan ASI yang tidak dapat digantikan oleh susu formula, ibu ingin bayi terhindar dari penyakit infeksi, pemberian ASI praktis, hemat dan ekonomis karena tidak mengeluarkan biaya sebesar penggunaan susu formula.

Mayoritas ibu hamil menginginkan agar bayi sehat. Menurut Walyani (2015) pemberian ASI memberikan banyak manfaat untuk kesehatan bayi antara lain memberikan kehidupan bayi yang lebih baik, mengandung antibodi untuk menghindarkan bayi dari penyakit infeksi, dan mengandung komposisi yang tepat sesuai dengan kebutuhan bayi. Distribusi ibu terhadap niat memberikan ASI Eksklusif diperoleh dari ibu yang memiliki pandangan sangat mendukung terhadap keyakinan berperilaku, evaluasi hasil, keyakinan normatif dan keinginan meniru. Kestabilan niat seseorang untuk melakukan suatu perilaku dapat dilihat berdasarkan jarak waktu antara pengukuran niat dan penilaian perubahan perilaku. Pengukuran niat bukanlah alat yang akurat dalam memprediksi perilaku seseorang.

Penelitian ini tidak sejalan dengan milik Jatmika (2015) yang menyatakan bahwa mayoritas responden memiliki niat yang rendah untuk memberikan ASI Eksklusif. Penelitian menyatakan bahwa rendahnya cakupan pemberian ASI Ekkslusif di wilayah kerja Puskesmas Gondokusuman dikarenakan rendahnya niat ibu hamil untuk memberikan ASI Eksklusif.

Faktor yang mempengaruhi niat ibu untuk memberikan ASI Eksklusif, yaitu sikap keyakinan berperilaku dan norma 
subyektif keinginan meniru. Berbeda dengan halnya faktor yang berpengaruh dalam penelitian Jatmika (2015) yang menyatakan bahwa usia kehamilan, norma sosial, pekerjaan ibu, dan pengalaman menyusui ibu akan mempengaruhi niat ibu untuk memberikan ASI Eksklusif (Jatmika, 2015).

Diantara kedua faktor tersebut terdapat faktor yang paling berpengaruh terhadap niat ibu untuk memberikan ASI Eksklusif yaitu variabel keyakinan berperilaku. Pandangan ibu hamil di Kelurahan Magersari, Sidoarjo terhadap keyakinan berperilaku yang diperoleh dari pertimbangan atas keuntungan maupun kerugian dalam melakukan pemberian ASI Eksklusif kepada bayi. Pertimbangan digambarkan dalam pernyataan mengenai pengertian ASI Eksklusif, keuntungan dan manfaat pemberian ASI Eksklusif kepada bayi.

Penelitian sesuai dengan Yuliani (2012), niat dalam memberikan ASI Eksklusif secara signifikan dipengaruhi oleh variabel sikap terhadap perilaku, norma subyektif dan persepsi kemampuan mengontrol. Penelitian berbeda dengan penelitian (Kurniawati, 2014) yang menyebutkan bahwa faktor yang paling mempengaruhi pemberian ASI Eksklusif yaitu keinginan meniru.

Keinginan untuk meniru yang didapatkan dari orang sekitar ibu, yaitu keluarga, teman atau orang terdekat yang berada di lingkungan sekitar ibu yang sedang hamil. Keinginan meniru dari teman mempunyai pengaruh yang cukup besar terhadap ibu untuk mendukung memberikan ASI Eksklusif. Penelitian Febryanti, Dwi Ernawati (2015) yang menyatakan bahwa faktor dominan yang paling mempengaruhi pemberian ASI Ekslusif adalah faktor kesehatan dan pekerjaan ibu.

\section{SIMPULAN}

Pada penelitian ini terdapat beberapa faktor yang diteliti yaitu keyakinan berperilaku, evaluasi hasil, keyakinan normatif dan keinginan meniru. Berdasarkan hasil penelitian didapatkan bahwa faktor yang mempengaruhi niat ibu memberikan ASI Eksklusif di wilayah Kelurahan Magersari, Sidoarjo antara lain keyakian berperilaku dan keinginan meniru. Keyakinan berperilaku seorang ibu diperoleh dari pengetahuan terhadap keuntungan maupun kerugian dari pemberian ASI Eksklusif. Sedangkan, untuk keinginan meniru seorang ibu didapatkan dari keberhasilan orangtua yaitu ibu dalam memberikan ASI Eksklusif sebelumnya.

\section{SARAN}

Saran yang dapat diberikan untuk ibu yaitu menambah pengetahuan dengan memperbanyak mencari informasi seputar keuntungan maupun kerugian dari pemberian ASI Eksklusif sebagai tambahan pengetahuan yang dimiliki agar ibu tetap memiliki keyakinan berperilaku yang baik guna mendukung perilaku pemberian ASI Eksklusif. Perilaku pemberian ASI Eksklusif perlu diberikan dan dijadikan sebagai suatu kewajiban bagi seorang ibu untuk menyusui agar generasi ibu berikutnya dapat meniru perilaku tersebut dan menghasilkan bayi yang sehat dan cerdas untuk masa depan bangsa yang baik. Saran untuk penelitian selanjutnya diharapkan mampu menggambarkan pengaruh antara niat terhadap perilaku pemberian ASI Eksklusif sehingga diketahui penyebab mengapa cakupan ASI Eksklusif masih rendah untuk wilayah Kabupaten Sidoarjo.

\section{DAFTAR PUSTAKA}

Danuatmaja, B., Mila, M. 2013 . 40 Hari Pasca Persalinan Masalah dan Solusinya. Jakarta: Pustaka Pembangunan Swadaya Nusantara.

Febriyanti, R., dan Dwi, E. 2015. Analisis Faktor-Faktor yang Mempengaruhi Pemberian ASI Eksklusif di Desa Gilang Taman Sidoarjo. Jurnal Keperawatan. [e-journal] 2014/2015: pp 7-10. Tersedia di $<$ https://www.google.co.id/search?sit $\mathrm{e}=\&$ source $=\mathrm{hp} \& \mathrm{q}=$ Febriyanti $\% 2 \mathrm{C}+\mathrm{Ro}$ salina+dan+Dwi+Ernawati.+2015.+An alisis+Faktor-Faktor+yang + Mempenga ruhi + Pemberian + ASI + Eksklusif + di + D esa+Gilang+Taman+Sidoarjo.+Jurnal+ \&oq $=$ Febriyanti $\% 2 \mathrm{C}+$ Rosalina + dan $+\mathrm{D}$ wi+Ernawati. $+2015>$ [diakses tanggal 27 Mei 2016]. 
Glanz, K., Barbara K. R., and K.Viswanath. 2008. Health Behavior and Health Education Theory, Research, and Practice. 4th Edition. United States of America : Jossey-Bass.

Ida. 2012. Faktor-faktor yang Berhubungan dengan Pemberian ASI Eksklusif 6 Bulan di Wilayah Kerja Kemiri Muka Kota Depok Tahun 2011. Tesis. Fakultas Kesehatan Masyarakat Universitas Indonesia Depok.

Jatmika, S. E. D. 2015. Norma Masyarakat Untuk Meningkatkan Niat Ibu Hamil Dalam Memberikan ASI Eksklusif. Jurnal Kesehatan "Samodra Ilmu". [e-journal] 06(01): pp 51-55. Tersedia di: <http:// download.portalgaruda.org/article.ph $\mathrm{p}$ ?article $=281800 \& \mathrm{val}=7164 \&$ title $=\mathrm{N}$ orma $\% 20$ Masyakarat $\% 20$ Untuk $\% 20$ Meningkatkan\%20Niat\%20Ibu\%20 Hamil\%20Dalam\%20Memberikan\%20 ASI\%20Eksklusif> [diakses tanggal 29 Mei 2016].

Kementrian Kesehatan RI. 2014. INFODATIN (Pusat Data dan Informasi Kementrian Kesehatan RI). Jakarta Selatan.

Kurniawati, D. 2014. Faktor Determinan yang Mempengaruhi Kegagalan Pemberian ASI Eksklusif pada Bayi Usia 6-12 bulan di Kelurahan Mulyorejo Wilayah Kerja Puskesmas Mulyorejo Surabaya.
Program Studi Kesehatan Masyarakat. Universitas Airlangga.

Laporan Puskesmas Sidoarjo. 2015. Bumil di Wilayah Puskesmas Sidoarjo. Sidoarjo : Puskesmas Sidoarjo.

Notoatmodjo, S. 2012. Metodologi Penelitian Kesehatan. Jakarta : Rineka Cipta.

Nurani, A. 2013. 7 Jurus Sukses Menyusui. Yogyakarta: Nuha Medika.

Roesli, U. 2008. Seri 1 Mengenal ASI Eksklusif. Taurus Agriwidya.

Soetjiningsih. 2012. ASI Petunjuk untuk Tenaga Kesehatan. Jakarta : Penerbit Buku Kedokteran EGC.

Sulistyowati, T., Siswantara, P. 2014. Perilaku Ibu Bekerja dalam Memberikan ASI Eksklusif di Kelurahan Japanan Wilayah Kerja Puskesmas KemlagiMojokerto. Volume 2 No. 1 Halaman 1-115. Jurnal Promosi Kesehatan Universitas Airlangga. Undang-Undang Nomor 20 Tahun 20013 tentang Sistem Pendidikan Nasional. Jakarta.

Walyani, E. S. 2015. Perawatan Kehamilan dan Menyusui Anak Pertama agar Bayi Lahir dan Tumbuh Sehat. Yogyakarta : Pustaka Baru Press.

Yuliarti, N. 2010. Keajaiban ASI -Makanan Terbaik untuk Kesehatan, Kecerdasan, dan Kelincahan Si Kecil. Yogyakarta : Andi Offset 